Technical Paper

\title{
Catalytic Decomposition of Chlorofluorocarbons with Directly Induced Heating System
}

\author{
Toshihiko OKADA *1, Minoru ASANUMA*1, Toshio TAKAOKA*1, Jun ISHII *1, Tatsuro ARIYAMA*1, \\ Ichiro UENO *2, and Kazumasa WAKIMOTO*3 \\ (Received June 12, 2003)
}

\author{
直接誘導加熱型触媒によるフロン類の分解 \\ 岡田敏彦*1, 浅沼 稔*1, 高岡利夫*1, 石井 純*1, 有山達郎*1, 上野一郎*2, 脇元一政*3
}

\begin{abstract}
Decomposition of Chlorofluorocarbons by a honeycomb packing with $\mathrm{Pt} / \mathrm{WO}_{3} / \mathrm{TiO}_{2}$ catalyst heated directly with an electromagnetic induced heating system was investigated at temperature of $400{ }^{\circ} \mathrm{C}$. The decomposition of CFCs in the heating system was found to give higher conversion than in a conventional heating method, which can be attributed to a higher controllability of reaction temperature in the system. The characterization of catalysts showed that the amount of coke formed on the catalyst after the reaction in the system was lower than in the conventional heating system.
\end{abstract}

Key Words

Chlorofluorocarbons, Induced heating, Catalysis

\section{1. 緒 言}

フロン類はオゾン層を破壊し，地球生態系に大きな影響を 与える物質である1。このため，その影響が大きい特定フロン については既に生産が禁止されており，我が国では冷媒用フ ロン類については回収し，適正に分解処理することが義務付 けられている2゙。さらに，冷蔵庫に使用されている断熱用ポリ ウレタンに含有されるフロン類についても同様な処理が義務 付けられる予定である。

廃亯物混焼法, 他製品製造工程混入法, 液中燃焼法, プラ ズマ法と触媒による接触分解法がフロンの分解処理法として 認定されているが2), この中で触媒法は低温処理が可能なこと から，効率的な処理方法と考えられている。フロン類の分解 触媒に関しては $\mathrm{MCln} / \gamma-\mathrm{Al}_{2} \mathrm{O}_{3}{ }^{3\rangle}$ や $\mathrm{WO}_{3} / \mathrm{MxOy}{ }^{4)}$ による $\mathrm{CFC}-$ 12 分解，活性炭に担持した鉄系触媒による CFC-112，㧍よび CFC-113の分解 ${ }^{5)}$ ， $\mathrm{TiO}_{2}$ 系触媒による CFC-113 分解6) ${ }^{6)}, \mathrm{AlPO}_{4}$ 触媒の分解性能8)，等が研究されており，いずれも $250^{\circ} \mathrm{C} \sim 400$ ${ }^{\circ} \mathrm{C}$ の温度領域で高い分解率でフロン類の分解が可能であるこ とが報告されている。なお，我が国では特定フロンの破壊技

\footnotetext{
* 1 Steel Research Laboratory, JFE Corporation 1 Kawasaki-cho, Chiba 260-0835, Japan

* 2 Recycle Business Center, JFE Corporation 2-2-3 Uchisaiwaicho, Chiyoda-ku, Tokyo 100-0011, Japan

* 3 Environment Solution Center, JFE Holdings, Inc. 1-1-2 Marunouchi, Chiyoda-ku, Tokyo 100-0005, Japan
}

術として $\mathrm{TiO}_{2}$ 系触媒と $\mathrm{AlPO}_{4}$ 系触媒を用いた触媒分解法が既 に認定されている2)。また, 一般に, 工業的な触媒反応では反 応に必要な熱源の供給手段として, 電気加熱, あるいは然料 燃焼による外熱方式や原料ガスを間接的に加熱し，これを反 応系に導入する方法が用いられている。これらの加熱方法で は, 触媒の局部的な過熱に起因する活性金属種の飛散, コー キングや触媒担体細孔の閉塞が発生し, この結果, 触媒劣化 が起こることが知られている。

本研究では触媒劣化対策や装置の安定運転が特に要求され る触媒法によるフロン類の分解法において, 触媒層内温度を 均一化することが可能であり, かつ加熱応答性が極めて速く, 触媒活性の変動を軽減できる加熱方式を開発した。この方式 は触媒を直接誘導加熱（触媒誘導加熱型フロン分解法）する ものであり, 加熱部が触媒層のみであるため, 触媒層内温度 を均一化することが可能となり, 触媒の寿命延長が期待でき る。また, 従来の外部加熱型に比べ, 熱容量が小さいため省 エネルギーが可能である。さらに, 腐食性ガスの発生を伴う 反応では反応に用いる金属材料の腐食速度が雾囲気温度によ

* 1 JFEスチール(株) スチール研究所 製銑・環境プロセス 研究部

干 260-0835 千葉県千葉市中央区川崎町 1

* 2 JFE スチール (株) 総合リサイクル事業センター 干100-0011 東京都千代田区内幸町 2-2-3

* 3 JFEホールディングス(株) 環境ソリューションセンター テ100-0005 東京都千代田区丸の内 1-1-2 
り大きく変化するため97, 腐食を制御するためにも均一な温度 管理が重要な因子である。

本報では， $\mathrm{WO}_{3} / \mathrm{TiO}_{2}$ 系触媒を充填した金属八二カムを直接 誘導加熱する触媒誘導加熱型フロン分解法について, フロン 類の分解特性や触媒性状の変化について報告する。

\section{2. 実験方法}

\section{1 触媒調製}

触媒は混練法により調製した。硫酸子タン水溶液にアンモ ニア水を滴下し，水酸化チタンを調㡀し，一昼夜乾燥後，金 属塩を混練し，触媒を調製した。

\section{2 触媒性能試験方法および試験条件}

触媒性能試験には流通式反応装置を用いた。内径 $10 \mathrm{~mm} の$ 金属製反応管内に触媒を充填し, 所定濃度に調整されたフロ ン含有ガスを触媒が充填された反応管に供給する。フロン標 準ガス (CFC-11またはCFC-12)，空気抢よび窒素はマスフロー コントローラーにより流量調整し，水はマイクロフィーダー により供給した。反応温度は触媒層内温度を熱電対で計測し， 所定温度になるように電気炉温度を調整した。反応後，ガス は苛性ソーダ水溶液，シリカゲルを充填したトラップを通気 し, 中和・脱水後, 残留する排ガス中フロン濃度をガスクロ で分析した。

標準的なフロン分解条件を以下に示す。反応ガス中フロン 濃度は筀素ガスで希釈して調整した。

・フロン濃度： $3 \%$ （供給する水を含まず）

・酸素/フロン比： 3 モル比

·水/フロン比：30 モル比

・総ガス基淮空間速度：7300h-1

・フロン基準空間速度 : $125 \mathrm{~h}^{-1}$

・触媒量： $2 \mathrm{ml}(1.2 \mathrm{~g})$

\section{3 直接誘導加熱型触媒フロン分解装置および試験条件}

Fig. 1に直接誘導加熱型触媒フロン分解装置の試験フローを 示す。本試験に用いたフロン ( CFC-11) 含有ガスは冷蔵庫断
熱材の熱処理で発生したものであり, その性状をTable 1に示 す。触媒誘導加熱型フロン分解装置は脱夕ール塔, 予熱器, 触 媒充填金属八二カムが設置されている高周波誘導加熱炉(Fig. 2), 分解瑷排ガスの冷却器および発生した $\mathrm{HCl}, \mathrm{HF} の$ 中和装 置（25\%苛性ソーダで中和し，pH存管理）から構成されてい る。なお，排力゙ス処理能力は $20 \mathrm{Nm}^{3} / \mathrm{h}$ である。また，分解後 の排ガス中のフロン濃度を経時的に把握するためにガスクロ マトグラフィーを設置した。

分解試験は以下のとおりの条件で実施した。すなわち，フ ロン含有ガス量を $20 \mathrm{Nm}^{3} / \mathrm{h}$ し，以下の試験条件を設定した。

·空気/フロン比：58モル比

·水/フロン比：30 モル比

·空間速度：5860h-1 (総ガス基準で, 触媒 3 段充填)

·処理温度 : $400^{\circ} \mathrm{C}$ (高周波加熱温度, 触媒層内)

触媒を金属八二カムに充填し，石英製反応管内に装入した。 フロン含有ガス導人前に空気在所定量供給しながら, 予熱器 を $105^{\circ} \mathrm{C}$ に設定, 高周波加熱炉を $400^{\circ} \mathrm{C}$ に設定する（内部触媒 温度で制御)。触媒層内温度は石英製反応管下端から $30 \mathrm{~cm} に$ 設置した熱電対により計測した。反応管内が所定温度に達し たら，水を供給した兴フロン含有ガスを導入し，フロン分解 試験老開始した。

な㧍, 加熱方法の比較として, 反応管に石英管の代わりに 金属製反応管 (SUS310S) を用い, これを誘導加熱する触媒の 外熱方法も実施した。また, 触媒の性状については, 元素分 析，X線回折，比表面積測定，熱天科測定を実施した。

Table 1 Property of CFCs containing gas used

\begin{tabular}{l|c}
\hline Component & Concentration \\
\hline Water & $2.8 \mathrm{Vol} \%$ \\
Tar & $0.38 \mathrm{~g} / \mathrm{Nm}^{3}$ \\
$\mathrm{CH}_{4}$ & $420 \mathrm{ppm}$ \\
$\mathrm{C}_{2}$ & $230 \mathrm{ppm}$ \\
$\mathrm{C}_{3}$ & $570 \mathrm{ppm}$ \\
$\mathrm{C}_{4}$ & $47 \mathrm{ppm}$ \\
$\mathrm{CFC}-11$ & $1800 \mathrm{ppm}$ \\
\hline $\mathrm{N}_{2}$ & $>99 \mathrm{Vol} \%$ \\
\hline
\end{tabular}

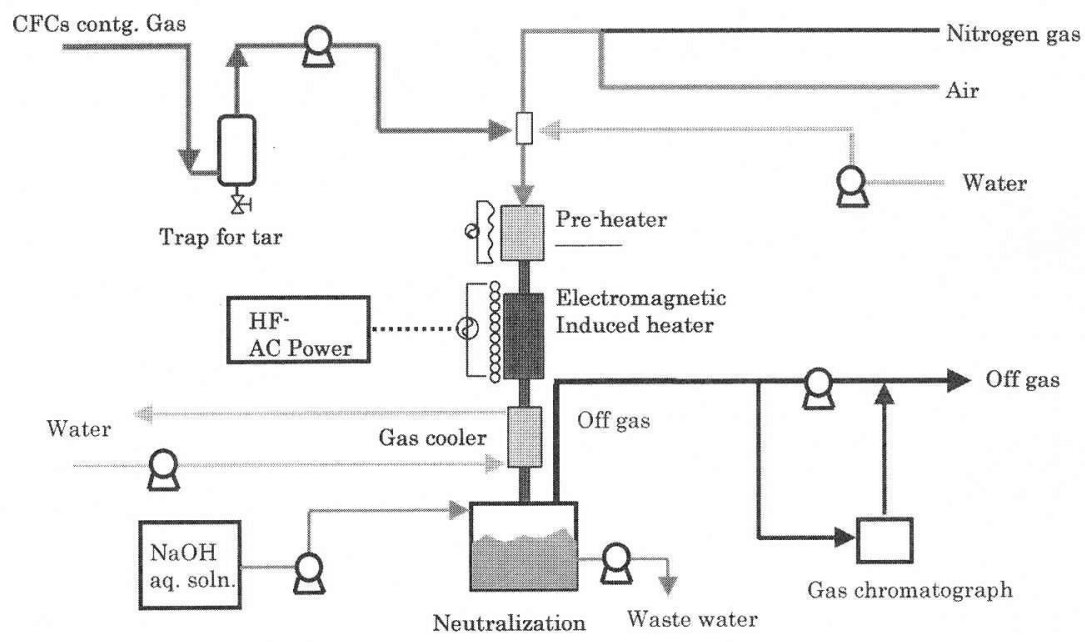

Fig. 1 Flow sheet of experimental equipment with direct induction heating system 


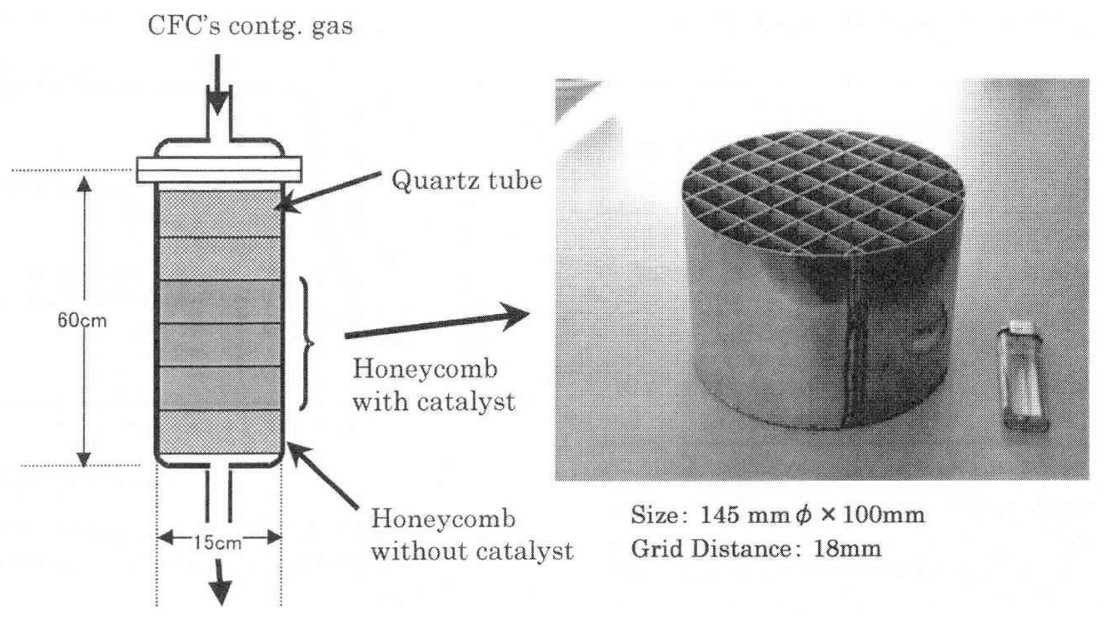

Fig. 2 Feature of Honeycomb for the catalytic decomposition of CFCs

\section{3. 試験結果および考察}

\section{1 触媒によるフロン分解反応}

触媒を用いたフロン分解反応として, 酸化分解, 水素化分 解や水蒸気分解反応が報告されているが，水蒸気分解反応が 反応制御や安全性の観点から実用的である7。本反応の機構は Fig. 3に示したように固体酸触媒上の反応と金属酸化物触媒で 再酸化を考慮した場合の 2 種類が考えられる。すなわち,

(1) 金属酸化物固体酸点上へのフロン吸着, 脱ハロゲンおよ び加水分解

(2) 金属酸化物上での脱八ロゲン, 金属酸化物のハロゲン化,

\section{加水分解 (再酸化)}

いずれの場合においても，本反応ではフロンの吸着と金属塩 化物, フッ化物の再酸化が容易な触媒系が高いフロン分解率 を与えることが予想される。また，本反応では，塩化水素や フッ化水素が生成するため, 長い触媒寿命を保持するために は触媒活性種掞よび担体としてはハロゲンとの親和性が少な いものが望まれる。

Fig. 4に金属ハロゲン化物生成エンタルピーと融点/分解温 度の関係を示すが, 上記要求性能を考虑すると, 以下の担体 および活性金属種が有利であることが分かる。

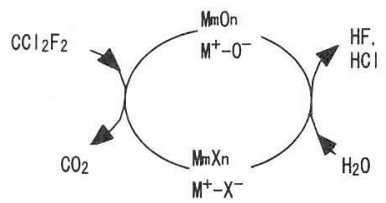

(1) Hydrolysis

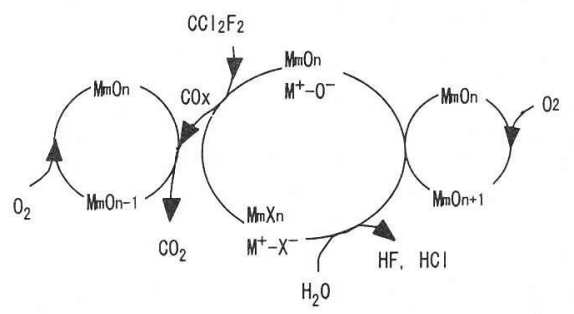

(2) Dehalogenation over metal oxides, halogenation of metal oxides and hydrolysis

$\mathrm{CCl}_{2} \mathrm{~F}_{2}+2 \mathrm{H}_{2} \mathrm{O}=\mathrm{CO}_{2}+2 \mathrm{HCl}+2 \mathrm{HF} \Delta \mathrm{H}_{0}=-160.2 \mathrm{KJ} / \mathrm{mol}$ (Exothermic)

Fig. 3 Mechanism in the catalytic decomposition of CFCs

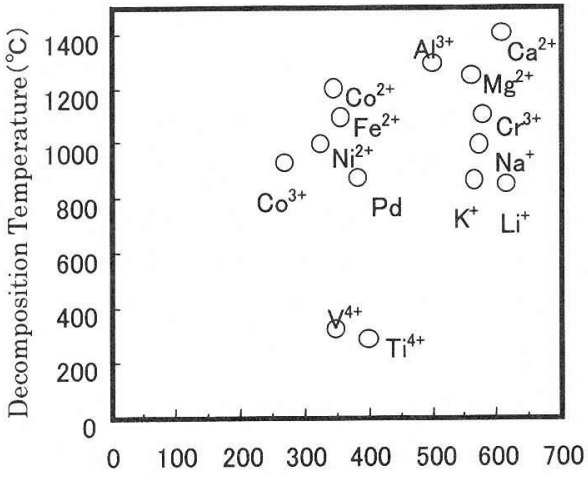

Formation Enthalpy of Metal chlorides $(\mathrm{kJ} / \mathrm{mol})$

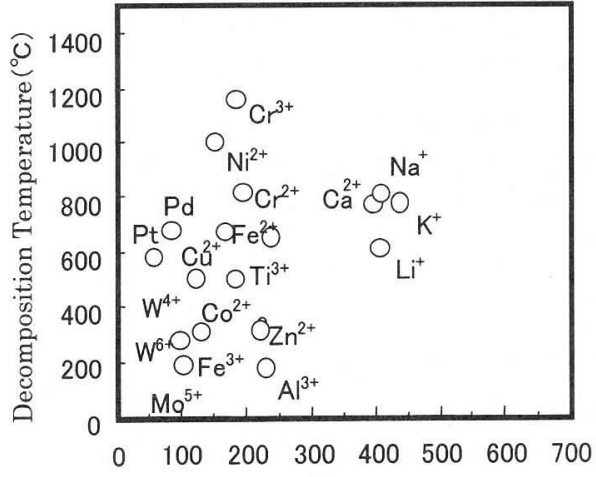

Formation Enthalpy of Metal chlorides (kJ/mol)

Fig. 4 Relation between formation enthalpy and decomposition temperature of metal halides 
Table 2 Catalytic activity of $\mathrm{WO}_{3} / \mathrm{TiO}_{2}$ in the decomposition of CFC-12

\begin{tabular}{|c|c|c|c|c|c|c|}
\hline Catalyst & \multicolumn{3}{|c|}{$\mathrm{WO}_{3} / \mathrm{TiO}_{2}$} & \multicolumn{3}{|c|}{$\mathrm{Pt}-\mathrm{WO}_{3} / \mathrm{TiO}_{2}$} \\
\hline Tempearture $\left({ }^{\circ} \mathrm{C}\right)$ & 300 & 350 & 400 & 300 & 350 & 400 \\
\hline CFC Conversion (\%) & 9.0 & 53.0 & 100 & 21.2 & 47.9 & 100 \\
\hline
\end{tabular}

Table 3 Catalytic activity of $\mathrm{WO}_{3} / \mathrm{TiO}_{2}$ in the decomposition of CFC-11

\begin{tabular}{l|c|c|c|c|c|c}
\hline \multicolumn{1}{c|}{ Catalyst } & \multicolumn{3}{c|}{$\mathrm{WO}_{3} / \mathrm{TiO}_{2}$} & \multicolumn{3}{c}{$\mathrm{Pt}-\mathrm{WO}_{3} / \mathrm{TiO}_{2}$} \\
\hline Tempearture $\left({ }^{\circ} \mathrm{C}\right)$ & 300 & 350 & 400 & 300 & 350 & 400 \\
CFC Conversion (\%) & 97.9 & 100 & 100 & 99.5 & 100 & 100 \\
\hline
\end{tabular}

Conditions ; space velocity $6800 \mathrm{~h}^{-1}$, concentration of CFC-11

$2 \mathrm{vol} \%$, molar ratio of air/CFCs 20 , molar ratio of $\mathrm{H}_{2} \mathrm{O} / \mathrm{CFCs} 27$

- 触媒担体 : $\mathrm{TiO}_{2}, \mathrm{Al}_{2} \mathrm{O}_{3}$

- 活性金属種：Fe, Ni, Co, Cu, V, W, Mo

本研究では，これらの担体や金属種のなかで，本反応の反応 温度などの特性を把握するため，菅野らが既に報告している $\mathrm{WO}_{3}$ 系触媒6) を用い，これを触媒系とする $\mathrm{CFC}-12$ お よびCFC11 の分解試験を行った。触媒としては $\mathrm{WO}_{3} / \mathrm{TiO}_{2}$ および $\mathrm{Pt}$ $\mathrm{WO}_{3} / \mathrm{TiO}_{2}$ の 2 種を用いた。結果をTable 2 と Table 3 に示す。 CFC-12の分解では，100\%のフロン分解率を達成するには400 ${ }^{\circ} \mathrm{C}$ の応温度が必要であり, 反応温度が $50^{\circ} \mathrm{C}$ 低下するとその 分解率は著しく低下し, 分解率は $53 \%$ となり, 本反応は温度 制御が極めて重要な因子であることが分かる。CFC-12に比べ てその影響は低いが, CFC-11の場合も同様な傾向を示す。Pt$\mathrm{WO}_{3} / \mathrm{TiO}_{2}$ 触媒はPtを担持していない触媒よりも高い触媒性能 を有するが，これは触媒表面に付着し，触媒性能を低下させ る有機物をPtが酸化除去するためと考えられる。

\section{2 直接誘導加熱型触媒フロン分解装置を用いた分解試験} フロン分解試験に先立ち，直接誘導加熱型触媒の昇温特性 について調査した。比較のための外熱式としては，石英製反 応管のかわりにSUS反応管を設置し，これを誘導加熱する方 法を用いた。金属ハニカムを 3 段充填した分解装置にフロン 分解試験と同様のガス量 (空気: $43.4 \mathrm{~L} / \mathrm{min}$, 窒素：300L/min) を供給して，予熱器を $105^{\circ} \mathrm{C}$ に設定し，触媒層内の昇温特性を 検討した。金属製反応管の場合，反応管が誘導を受け加熱さ れ，反応管内部の触媒に熱が供給され，石英製反応管を用い た場合では金属八ニカムが直接誘導を受け加熱される。

Fig. 5 に昇温開始からの経過時間と触媒層内温度推移を示 す。昇温速度はいずれの加熱方式とも $10^{\circ} \mathrm{C} / \mathrm{min}$ に設定した。 金属ハニカムを直接加熱した場合は，金属製反応管に比較し て極めて加熱が速く，応答性がきわめて良好であった。

フロン分解触媒としてPt-WO $3 / \mathrm{TiO}_{2}$ 触媒を用い，金属八二カ ムを直接誘導加熱した場合のフロン分解における分解率と排 ガス中のフロン濃度の経時変化を Fig. 6 に示す。

約25時間のフロン分解試験を実施した結果，加熱直後にフ ロン分解率，フロン残存濃度ともに安定した值を推移するこ

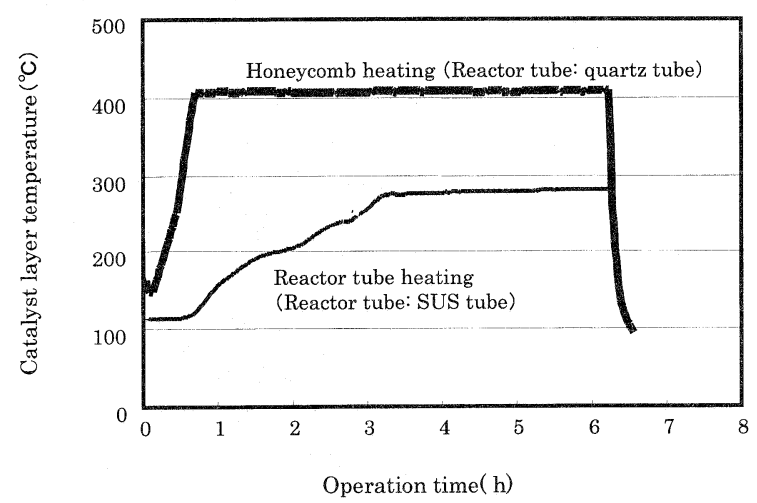

Fig. 5 Heating profiles in two types of heating methods Conditions; setting temperature $400{ }^{\circ} \mathrm{C}$, gas flow rate 20 $\mathrm{Nm}^{3} \mathrm{~h}$

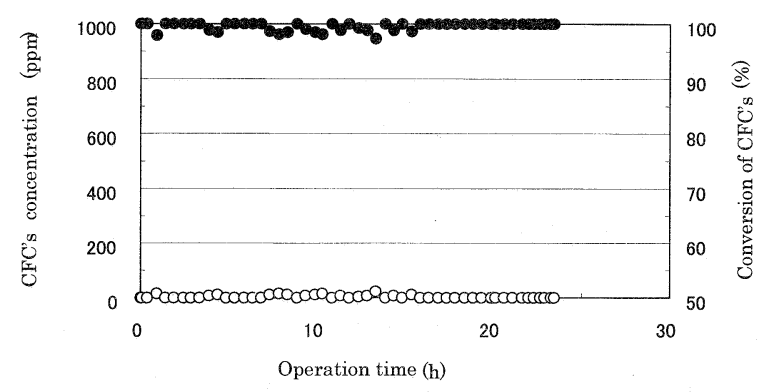

Fig. 6 Decomposition of CFCs with honeycomb catalysts heating by electromagnetic induction heating system $O$ : concentration of CFCs, : conversion of CFCs Conditions; space velocity $6000 \mathrm{~h}^{-1}$, molar ratio of gas/air 5.87, molar ratio of gas/ $\mathrm{H}_{2} \mathrm{O} 9.12$

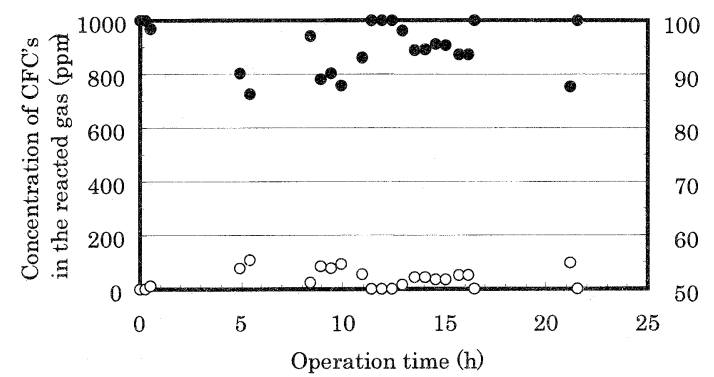

$\widehat{\alpha}$
0
0
0
0
0
0
0
0
00
00
0
0
0
0

Fig. 7 Decomposition of CFCs with SUS tube heating by electromagnetic induction heating system

: concentration of CFCs, : conversion of CFCs Conditions; space velocity $600 \mathrm{Oh}^{-1}$, molar ratio of gas/air 5.87, molar ratio of gas/ $\mathrm{H}_{2} \mathrm{O} 9.12$

とが明らかとなり，フロン分解率は $99 \%$ 以上を示した。 比較のために，金属製反応管を用いた外熱方式で分解した 結果をFig. 7 に示す。試験時間約 20 時間内においてフロン分 解率は $90 \%$ 以上を推移したが, 触媒活性に大きな変動が認め られた。これは触媒層温度の応答性が低い上に, 温度变動が 大きいためと推定される。

本反応はフロン分解に伴い，触媒として用いた金属および 金属酸化物が発生する塩化水素およびフッ化水素と反応し, 金属八ロゲン化物に変換されるため, 触媒の性能低下が懸念 される。そこで, その影響を調査するため, 触媒の性状変化 について解析を行った。 
Table 4 Properties of catalyst after the decomposition of CFCs containing gas (SUS reactor tube heating, after 20h)

\begin{tabular}{l|c|c|c|c}
\hline \multirow{2}{*}{ Catalyst } & Surface Area & \multicolumn{3}{|c}{ Approximate analysis (wt\%) } \\
\cline { 3 - 5 } $\mathrm{m}^{2} / \mathrm{g}$ & $\mathrm{C}$ & $\mathrm{Cl}$ & $\mathrm{F}$ \\
\hline Fresh & 86 & Trace & - & - \\
Upper layer & 77 & 5.29 & $<0.01$ & 0.03 \\
Middle layer & 80 & 2.36 & $<0.01$ & 0.01 \\
Bottom layer & 45 & 0.09 & $<0.01$ & Trace \\
\hline
\end{tabular}

Table 5 Properties of catalyst after the decomposition of CFCs containing gas (Honeycomb heating, after 25h)

\begin{tabular}{l|c|c|c|c|c|c|}
\hline \multirow{2}{*}{ Catalyst } & Surface Area & \multicolumn{4}{|c|}{ Approximate analysis(wt\%) } & \multirow{2}{*}{$\mathrm{C} / \mathrm{H}$} \\
\cline { 3 - 6 } & $\mathrm{m}^{2} / \mathrm{g}$ & $\mathrm{C}$ & $\mathrm{H}$ & $\mathrm{Cl}$ & $\mathrm{F}$ & \\
\hline Fresh & 83 & Trace & - & - & - & \\
Upper layer & 78 & 3.47 & 0.27 & $<0.01$ & 0.03 & 1.07 \\
Niddle layer & 73 & 0.65 & 0.15 & $<0.01$ & Trace & 0.36 \\
Bottom layer & 41 & 0.02 & 0.11 & $<0.01$ & Trace & 0.02 \\
\hline
\end{tabular}

金属製反応管を用い，外熱方式で分解反応を行った後の触 媒の元素分析結果および比表面積測定結果をTable 4に, 石英 製反応管を用い，直接誘導加熱したものをTable 5にそれぞれ 示す。使用後触媒にはいずれの場合も炭素，塩素，フッ素が 検出されたが，フロンの分解で発生し，触媒と反応して残存 するものと推定される塩素，フッ素の量は微量であった。ま た，反応管上段から下段における炭素発生量を比較すると直 接誘導加熱方式の方が外熱方式よりもいずれも少ない。一方, 触媒の比表面積は使用前触媒，上段使用済み触媒，中段，下 段の順に減少寸る傾向はあるが，雨方式で大きな差異は認め られなかった。Fig.8には触媒の細孔分布を示す。金属製，石 英製反応試験の反応管上段触媒に掠いて，使用前の触媒に比 べ120Å以上の細孔の減少が認められ，下段触媒においては逆 に200Å以下の細孔が減少し，それ以上の細孔径の増加が認め られた。石英製反応試験使用後の各層触媒の水素分析結果か ら $\mathrm{C} / \mathrm{H}$ (原子比) を算出したところ (Table 5)，触媒層により 大きく異なり，下部ほど $\mathrm{C} / \mathrm{H}$ 低い傾向を示した。これは，各 触媒層に吸着あるいは析出する物質が異なることを示す。す なわち，上部の触媒ではすぐにタールなどの熱分解で炭化が

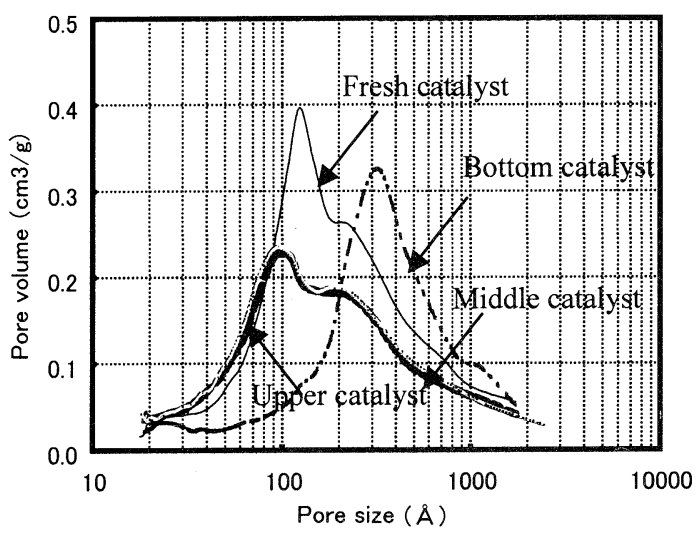

(a) SUS reactor tube heating
進行し，炭素析出が起こるのに対し，中部，下部では上部の 熱分解で生成した低分子等が $200 \AA$ 的下細孔に吸着，分解す るものと推察される。また, 外熱加熱方式に比へ, 誘導加熱 方式では中部の細孔分布が大径側にシフトしているので，そ の熱分解が抑制されているものと考えられる。

以上のように，金属製反応管を用いた場合に比較して石英 製反応管を用いた直接誘導加熱方式では，生成する炭素量が 少ないなどの特徴が明らかとなった。これは金属製反応管に 比べて石英製反応管を用いた直接誘導加熱方式が均一加熱に 有利なためと考えられる。炭素析出量を削減できれば，触媒 寿命も長くなり，触媒再生までの時間を延長できるので，本 知見は装置運転上，非常に有益である。なお，使用後触媒に $\mathrm{Cl}$ ，Fが微量検出されたことから，X線回折測定を実施したが， 八ロゲン化物の生成は認められなった。次に，反応後の触媒 に析出した炭素の除去，すなわち，触媒の再生条件を検討す るため，空気雲囲気での熱重量測定を行った。Fig. 9に示すよ

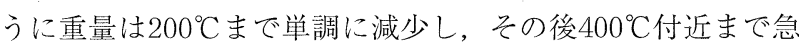
激に減少し，400 $450^{\circ} \mathrm{C}$ でその重量減少が終了する。減少量 が元素分析の炭素量とほぼ一致し, $400^{\circ} \mathrm{C}$ 強で重量減少が終了 することから，200 $\mathrm{C}$ な゙の重量減少は主に吸着水の減少， $400^{\circ} \mathrm{C}$ までの減少は触媒中の炭素の燃焼によるものと考えられ る。触媒担体として用いた $\mathrm{TiO}_{2}$ は $600^{\circ} \mathrm{C}$ 程度からアナターゼ 型から比表面積, 細孔構造が小さく, 触媒活性に乏しいルチ

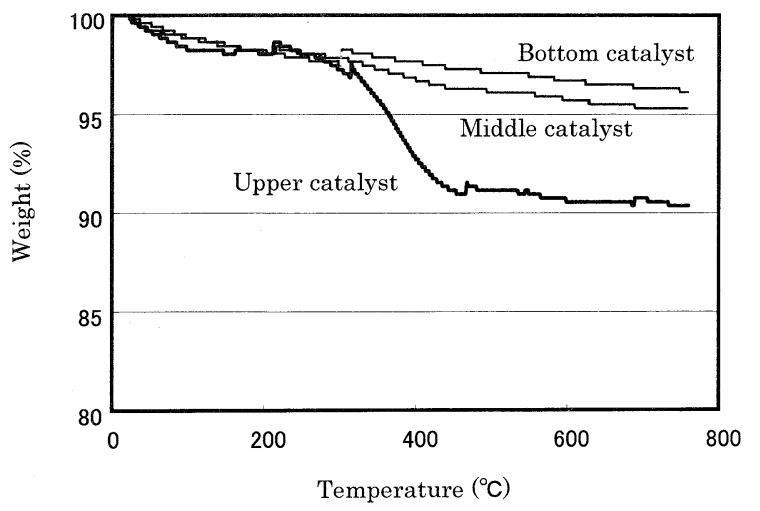

Fig. 9 Thermogravimetric analysis of catalyst after the reaction

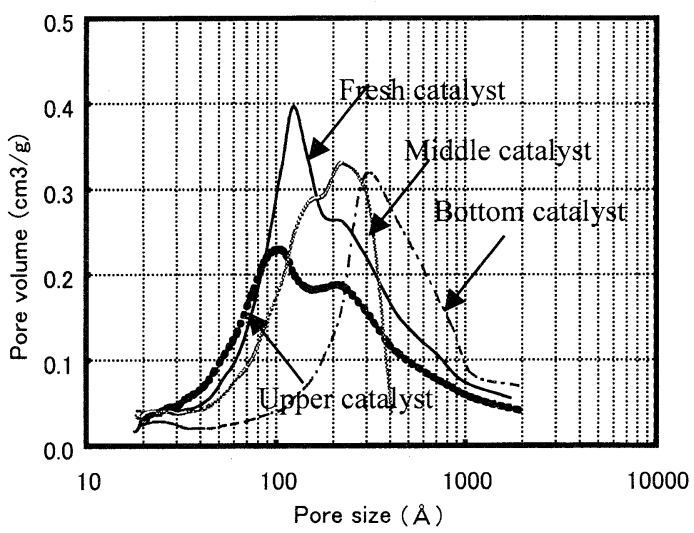

(b) Honeycomb heating

Fig. 8 Change in pore distribution of catalyst after the reaction 
ル型に転移するため ${ }^{10)}$, 再生は $500^{\circ} \mathrm{C}$ の温度が必要条件である が，本結果から $500^{\circ} \mathrm{C}$ 以下で再生が可能であることがわかる。 触媒性状については今後, さらに詳細な解析が必要であるが, 直接誘導加熱する本法によれば従来の外部加熱方式による触 媒分解プロセスに比べ, 長時間の触媒寿命が期待できる。

\section{4. 結 論}

直接誘導加熱型触媒分解法によるフロン分解技術を検討し た結果, $\mathrm{WO}_{3} / \mathrm{TiO}_{2}$ 系触媒を用い, 触媒を充填した金属八二カ 厶を誘導加熱する方法は, ほぼ $100 \%$ のフロン分解率を達成 し，長時間の安定した連続分解が可能であった。これは，触 媒誘導加熱方式が外熱方式と比へ, 急速加熱, 均一加熱が可 能なためと推察された。

\section{文 献: References}

1) Molina, M. J., and Lawland, F. S., Nature, 249, 810 (1974)

2）通産省，冷凍空調設備，27, 30(2000)

3) Fai Ng, C., Shan, S., and Lai, S. Yin, Appl. Catal. B: Environmental, 20, 919(1998)

4) Ma, Z., Hua, W., Tang, Y., and Gao, Z., J. Mol. Catal. A: Chemical, 159, 335 (2000)

5) Okazaki, S., and Kurosaki, A., Chem. Lett., 1989, 1901 (1989)

6) Kanno, S., Arato, T., Kato, A., Yamashita, H., Azuhata, S., and Tamata, S., Nippon Kagaku Kaishi, 1996, 129 (1996)

7) Tajima, M., Niwa, M., Fuji, Y., Koinuma, Y., Aizawa, R., Kushiyama, S., Kobayashi, S., Mizuno, K., and Ohuchi, H., Appl. Catal. B: Environmental, 14, 97 (1997)

8) Takita, Y., Sekiyu Gakkaishi, 44, 92 (2001)

9）芝川重博, 産業機械, 413(1985)

10) DeVries, R. C., and Roy, R., Am. Ceram. Soc. Bull., 33, 370 (1954) 